\title{
CHEK2 gene alterations independently increase the risk of death from breast cancer in Bulgarian patients
}

\author{
S. G. ANGELOVA*, M. E. KRASTEVA, Z. I. GOSPODINOVA, E. I. GEORGIEVA
}

Institute of Plant physiology and Genetics, Department of Molecular Genetics, Bulgarian Academy of Sciences, Acad. G. Bonchev Street, Bldg. 21, 1113 Sofia, Bulgaria

${ }^{*}$ Correspondence: svetla_georgieva@abv.bg

\section{Received March 16, 2012 / Accepted May 1, 2012}

\begin{abstract}
Checkpoint kinase 2 (CHEK2) is a DNA damage-activated protein kinase implicated in cell cycle checkpoint control. The significance of CHEK2 alterations for breast cancer incidence and clinical behavior is not clear. In this study we determined the mutational spectrum and the level of promoter hypermethylation of CHEK2 gene in a group of 145 Bulgarian patients with breast cancer. A special emphasis was put on the clinical impact of CHEK2 alterations for breast cancerogenesis.

PCR-SSCP-sequencing analysis of the entire coding sequence of CHEK2 gene was performed to estimate the mutational profile of tumor samples. Methylation-sensitive SSCP was applied to determine the methylation status in CpG clusters implicated in CHEK2 silencing. Clinical significance of CHEK2 alterations was evaluated using standard statistical methods.

Mutations in CHEK2 were identified in $9.65 \%$ of the patients. Two novel missense substitutions Thr476Met $(\mathrm{C}>\mathrm{T})$ and Ala507Gly $(C>G)$, and a novel silent variant Glu79Glu $(A>G)$ were registered. However, hypermethylation was not found in any of the studied cases. Comparison with clinical characteristics showed that CHEK2 positive women have predominantly lobular type of breast carcinoma $(\mathrm{p}=0.04)$ and $\mathrm{PR}^{+}$status $(\mathrm{p}=0.092)$. CHEK2 mutations correlated significantly with $A_{T} M^{+}$ status $(\mathrm{p}=0.046)$. All patients with the Glu79Glu variant were progesterone receptor positive $(\mathrm{p}=0.004)$. A decrease in overall survival $(\mathrm{p}=0.6301)$ and a threefold increased independent risk of death $(\mathrm{HR}=3.295,95 \% \mathrm{CI} 0.850-12.778, \mathrm{p}=0.085)$ in CHEK2 $2^{+}$patients was found.

Our data indicate the significance of $C H E K 2$ gene alterations in contrast to promoter hypermethylation in breast cancerogenesis. Specificity of CHEK2 mutational profile for the Bulgarian population was found. Though CHEK2 mutational status correlated with more favorable clinical characteristics, including positive progesterone receptor and lobular histological type, it independently increased the risk of death in these patients.
\end{abstract}

Key words: breast cancer, CHEK2, mutation, hypermethylation, clinico-pathological characteristics, overall survival

Breast cancer (BC) is the most common female malignancy and the most frequent cause of female cancer mortality. The incidence of BC in Bulgaria amounts to $23 \%$ of all women cancers, with about 3800 new cases diagnosed each year [1]. $\mathrm{BC}$ tumorigenesis is a complex, multi-step process, in which each step is thought to correlate with one or more abnormal genetic as well as epigenetic changes in genes involved in cell regulation $[2,3]$.

Abbreviations: WT - wild type; $\mathrm{T}$ - tumor size; $\mathrm{N}$ - nodal status; G - grade of malignancy; HT - histological type; ER - estrogen receptor; PR - progesterone receptor. Significant p values are in bold.
Cell cycle checkpoint kinase 2 (CHEK2, also known as "CHK2" [MIM 604373]) is a multifunctional kinase with a key significance for cell cycle regulation in response to DNA double strand breaks thus contributing to maintenance of genome stability $[4,5]$. The human CHEK2 gene consists of 14 coding exons and spans approximately $50 \mathrm{~kb}$ of genomic DNA. It encodes a 543 amino acids nuclear serine-threonine kinase with three characteristic domains: an N-terminal SQ/TQ cluster domain (amino-acid residues 20-75), a fork head-associated (FHA) domain (residues 112-175) and a serine/threonine kinase domain (residues 225-490) [6]. CHEK2 kinase is expressed in the vast majority of normal human tissues including many nonproliferating, terminally 
differentiated cells [7]. In response to DNA damage induced by ionizing radiation, CHEK2 is activated through phosphorylation of Thr68 by ATM protein [5, 8-10]. When double strand breaks are caused by UV irradiation or hydroxyurea treatment, CHEK2 is likely to be activated by ATR kinase $[10,11]$. After oligomerization and auto-phosphorylation [12], CHEK2 kinase moves throughout the nucleoplasm to transmit the damage signal by phosphorylating several essential cell-cycle proteins including: p53 [11], Cdc25A [12] and Cdc25C phosphatases [9] and BRCA1 [13]. This triggers cellular pathways are involved either in cell-cycle arrest at G1/S, S, and G2/M phases [14, 15] and DNA repair, or apoptosis $[5,16]$.

The first evidence suggesting implication of CHEK2 in cancer development was the germline mutation 1100delC found in several Li-Fraumeni and Li-Fraumeni-like families [17]. Importantly, germ-line mutations within the CHEK2 gene have been reported in a subset of Li-Fraumeni families who have a wild-type $p 53$, suggesting that CHEK2 may function as a tumor suppressor. The consideration of CHEK2 as a new tumor suppressor gene has been supported by the identification of germline and somatic mutations in a range of human tumors including breast, colon, ovarian, vulva, prostate and others [18-26]. On that basis CHEK2 is proposed as a multiorgan cancer susceptibility gene [27]. CHEK2 frequency and spectrum of mutations displayed considerable differences between populations and between familial and sporadic cases. Lately the $1100 \mathrm{delC}$ variant is evidently associated with a threefold increased risk of breast cancer in heterozygous women from the general population and may also increase the risk of other cancers [28]. In contrast to germ-line mutations in family cases, which are extensively studied, limited data on CHEK2 mutational frequency and spectrum in sporadic breast cancer is available. The CHEK2 somatic mutations in sporadic breast cancer are relatively rare [29], and some studies assumed the possibility that, except genetic alterations, alternative mechanisms like epigenetic promoter hypermethylation could silence CHEK2 expression [20]. Promoter hypermethylation may serve as a basis for cancer development and has been described in several tumor suppressor genes like the $R B$ gene in retinoblastoma [30], the $V H L$ gene in clear cell renal carcinoma [31], the ATM gene in head and neck squamous cell carcinoma [32], the BRCA1 gene in sporadic breast cancer [33] and others. Limited studies investigated the hypermethylation status of CHEK2 gene in breast [20, 29], lung [34, 35], lymphoid [36], non Hodgkin lymphomas [37], vulval [22], ovarian [20], colorectal tumors [38], gliomas [39].

So far, a general clinical impact of CHEK2 cannot be established due to the limited populations studied and the specificity in type and frequency of the found alterations. This study represents a combined genetic and epigenetic analysis of CHEK2 gene in sporadic breast cancer with a special emphasis on evaluation of CHEK2 clinical significance. The frequency and spectrum of genetic alterations and the level of epigenetic promoter hypermethylation in CHEK2 were determined in a group of 145 breast cancer patients. Specific mutational profile of CHEK2 gene for the Bulgarian population was found. Statistically significant clinical correlations were registered.

\section{Patients and methods}

Breast tumors were obtained from 145 Bulgarian female unrelated patients who were treated at the Thoracic Surgery Clinic of the National Oncological Centre (Sofia, Bulgaria) between 2000 and 2003. Cases were staged according to the TNM classification of Union International Contre le Cancer (UICC). The age of breast cancer women was in the range of 29-88 years, with a mean age of 54.4 years. Histologically, 130 invasive ductal carcinomas and 15 invasive lobular carcinomas were identified. Six patients had highly differentiated tumors (G1), 103 - moderately differentiated (G2) and 36 - poorly differentiated (G3). Ninety-two patients had negative nodal status and 53 - positive. Sixty-four patients were ER-negative, 81 - ER-positive. PR-negative were 64 patients, PR-positive - 81. Tumor samples were previously characterized according to p53, BRCA1, ATM, PIK3CA mutational status and HER2 level of expression [40]. Patients underwent adjuvant therapy according to the accepted practice guidelines at that time. The women were followed for a median period of 69 months (range from 11 to 96 months). The follow-up time began at the time of surgery and ended in November 2008 or at the date of death. Blood samples of clinically healthy persons were used as negative controls. Written consent was taken from all participants in the study. Clinical information was obtained from the existing medical records and is presented in a way preventing patients' identification.

DNA isolation. Tumor DNA was isolated from fresh frozen breast tumors by a standard Proteinase K/Phenol procedure including tissue homogenization in lysis buffer $(10 \mathrm{mM}$ Tris/ $\mathrm{HCl} \mathrm{pH} \mathrm{8.3,400mM} \mathrm{NaCl,} 2 \mathrm{mM}$ EDTA-Na, $0.14 \mathrm{mg} / \mathrm{ml}$ Proteinase $\mathrm{K}, 1 \% \mathrm{SDS}$ ) at $37^{\circ} \mathrm{C}$ for $48 \mathrm{~h}$, phenol/chloroform/isoamyl alcohol purification and ethanol precipitation. DNA was isolated from blood sample of healthy controls by a standard procedure. DNA concentration and purity was determined using BioSpec-nano Spectrophotometer (Shimadzu Biotech).

Single-strand conformational polymorphism analysis. The 14 coding exons of the CHEK2 were amplified using 15 primer sets according to Liu Wei-Dong et al [41] (Table 1). PCR reactions were done in a total volume of $25 \mu$ containing $50 \mathrm{ng}$ of template DNA, 1x PCR buffer, $2.25 \mathrm{mM} \mathrm{MgCl}_{2}$, $0.2 \mathrm{mM}$ of each dNTP, $100 \mathrm{nM}$ of each primer and 0.5 units of Taq DNA polymerase (Netzyme). The cycling reactions included 35 cycles of denaturation at $94^{\circ} \mathrm{C}$ for $30 \mathrm{sec}$ (first cycle $-5 \mathrm{~min}$ ), annealing at the appropriate temperature (see Table 1) for $30 \mathrm{sec}$ and elongation at $72^{\circ} \mathrm{C}$ for $30 \mathrm{sec}$ (last cycle -12 min.).

The amplified products were denatured in $95 \%$ formamide, $0.01 \mathrm{~N} \mathrm{NaOH}(1: 1.4)$ at $95^{\circ} \mathrm{C}$ for $10 \mathrm{~min}$ and separated on 
Table 1. CHEK2 primers used for SSCP and for methylation-sensitive SSCP analysis

\begin{tabular}{|c|c|c|}
\hline $\begin{array}{l}\text { Exon/ } \\
\text { Primer }\end{array}$ & Sequence $\left(5^{\prime}-3^{\prime}\right)$ & $\begin{array}{c}\text { Annealing } \\
\text { temperature } \\
\left({ }^{\circ} \mathrm{C}\right)\end{array}$ \\
\hline \multicolumn{3}{|c|}{ PCR primers used for SSCP analysis } \\
\hline 1a & $\begin{array}{l}\text { F TAAGTCTTGTGCCTTGAAACTCACC } \\
\text { R AGAGCTGGAGTGAGAGGACTG }\end{array}$ & 64 \\
\hline $1 b$ & $\begin{array}{l}\text { F CCAGCACGATGCCAAACTCCA } \\
\text { R CGTGATACTATACAACAAAGGGTC }\end{array}$ & 64 \\
\hline 2 & $\begin{array}{l}\text { F TCAACAGCCCTCTGATGCATGC } \\
\text { R CAGCTCTCCTAGATACATGGGTAT }\end{array}$ & 64 \\
\hline 3 & $\begin{array}{l}\text { F GGAGAGCTGGTAATTTGGTC } \\
\text { R TTTCCTCCTATGAGAGAGTGG }\end{array}$ & 64 \\
\hline 4 & $\begin{array}{l}\text { F GAATCAGTGATCGCCTCTTGTG } \\
\text { R GAGAAACCACCAATCACAAATGTATAGTG }\end{array}$ & 65 \\
\hline 5 & $\begin{array}{l}\text { F ACCCAGAGTGGTAGGTCTC } \\
\text { R TGATCAGCCTTTTATTGGTACTTA }\end{array}$ & 63 \\
\hline 6 & $\begin{array}{l}\text { F GGCAGCCTTGAGTCAACTGAG } \\
\text { R TACTGAAAGGCTTTATACTCTTCTC }\end{array}$ & 62 \\
\hline 7 & $\begin{array}{l}\text { F GGGAGTTTCTCACTACTTTCCC } \\
\text { R CAGGATGAGAAAGGCAAGCCTACA }\end{array}$ & 64 \\
\hline 8 & $\begin{array}{l}\text { F CCCTTGCCTTGCCTTTGTGTTTC } \\
\text { R GGCAGCTGTCAAAAGAATTGAGG }\end{array}$ & 64 \\
\hline 9 & $\begin{array}{l}\text { F ACGGCTTACGGTTTCACC } \\
\text { R CAAGAATCTACAGGAATAGCC } \\
\end{array}$ & 64 \\
\hline 10 & $\begin{array}{l}\text { F CTTGGACTGGCAGACTATG } \\
\text { R CTCCTACCAGTCTGTGCAG }\end{array}$ & 62 \\
\hline 11 & $\begin{array}{l}\text { F GCCACTGAGAATGCCACTTGATTTC } \\
\text { R CCACCACAGCACATACACATT }\end{array}$ & 64 \\
\hline 12 & $\begin{array}{l}\text { F ACTGTGATTTGCCCAATTGTTGC } \\
\text { R ATGCTAGCAGGCACTGTCCC }\end{array}$ & 64 \\
\hline 13 & $\begin{array}{l}\text { F ATGCTAGCCCTGTCATTCTAGGA } \\
\text { R CTACATTTAGTGATCATCAGGAATACG }\end{array}$ & 63 \\
\hline 14 & $\begin{array}{l}\text { F CTTTACTGGAAGCATATTGAGG } \\
\text { R TTAATTGTACATCAGTGACTGT }\end{array}$ & 55 \\
\hline PCR pr & imers used for methylation-sensitive SSCP analysi & \\
\hline MIP1 & $\begin{array}{l}\text { F TTGTTGTTTAGGTTGGAGTGTAGTG } \\
\text { R AAAAACTCATAAAAACTTACATTTATCCA }\end{array}$ & 56 \\
\hline MIP2 & $\begin{array}{l}\text { F GAGTGGGGTTAGGTGTTTGTAG } \\
\text { R CCAACCAATCAACAACATTAATCTA }\end{array}$ & 59 \\
\hline MIP3 & $\begin{array}{l}\text { F GGTTTTTTTATTTTTTTTAATTTTAG } \\
\text { R AACAAATTCTTCTACСCACAATACC }\end{array}$ & 52 \\
\hline MIP4 & $\begin{array}{l}\text { F TTTTTGAGAAATTAAGATATTTTTTTTA } \\
\text { R AACAAATTCTTCTACCCACAATACC }\end{array}$ & 50 \\
\hline MIP5 & $\begin{array}{l}\text { F GTTATTTTGTTGGTTGAGGTTG } \\
\text { R TCTTCTTATCCTATATATTCAAACCTATTT }\end{array}$ & 50 \\
\hline
\end{tabular}

native polyacrylamide gels in $1 \mathrm{xTBE}$ buffer at $15 \mathrm{~mA}, 4^{\circ} \mathrm{C}$. The polyacrylamide gel concentration varied between 6 to $14 \%$ depending on the exon. Modified silver staining method was applied for visualization. Briefly, the gels were soaked in $50 \%$ methanol for $1 \mathrm{~h}$, then transferred to ammonium-silver solution, containing $0.02 \mathrm{~N} \mathrm{NaOH}, 0.375 \% \mathrm{NH}_{4} \mathrm{OH}$, and $0.8 \%$ $\mathrm{AgNO}_{3}$ for $15 \mathrm{~min}$ and washed with $500 \mathrm{ml} \mathrm{dH}_{2} \mathrm{O}$ for $10 \mathrm{~min}$. The staining reaction was developed by the use of $0.01 \%$ citric acid, $0.035 \%$ formaldehyde, and the gels were fixed in $0.5 \%$ acetic acid.

Amplified products with altered electrophoretic mobility were purified (GFX PCR DNA and Gel Band Purification Kit, Amersham Biosciences) and sequenced on ABI PrismTM 310 fluorescent sequencing analyzer (DYEnamicTM ET Terminator Cycle Sequencing Kit, Amersham Biosciences) following the manufacturers' instructions. To confirm the mutation all mutant samples were subsequently sequenced in the reverse direction. The sequence data of CHEK2 gene was obtained from GenBank.

Methylation-sensitive SSCP. The methylation status of CHEK2 promoter was determined by Methylation-sensitive PCR- SSCP analysis of sodium bisulfite-converted DNA. To convert DNA, EZ DNA Methylation KitTM was used following the manufacturer's recommendations (Zymo Research Corporation). One $\mu \mathrm{g}$ of DNA of each sample was subjected to conversion. The obtained pure modified DNA was further PCR analyzed using four sets of primers (MIP2, MIP3, MIP4, and MIP5) covering a total of CpGs in the distal CpG island (located 6,000-8,000 bp upstream of the translation initiation site), and one set of primers (MIP1) targeting the proximal CpG region (300-600 bp upstream of the translation initiation site) (Table 1). Primer sequences and amplification conditions were according to Louise $\mathrm{H}$. Williams [20]. The PCR products were SSCP analyzed as described above. We included in each assay a totally methylated in vitro DNA (Zymo Research) as a positive control, and a normal blood sample DNA as a negative control. The methylation status of representative methylation-sensitive SSCP products was confirmed by bisulfite sequencing (ABI PrismTM 310).

Statistical analysis. The relationship between CHEK2 alterations and clinico-pathological characteristics of patients was evaluated by Fisher's exact test and the Chi-squared test. Overall survival (OS) was estimated by the Kaplan-Meier method, and differences between survival curves were assessed for statistical significance using the log-rank test. Cox proportional hazards regression model was used to calculate the hazard ratios (HR) and their 95\% confidence intervals $(95 \% \mathrm{CI})$ for each variable in the univariate and multivariate analyses. All p-values were two-sided, and results were considered statistically significant at $p$ less than 0.05 . Analyses were done with the SPSS software package (SPSS Inc., Chicago, IL, USA).

\section{Results}

Mutational analysis of CHEK2 gene. The group of $145 \mathrm{BC}$ patients was assessed for CHEK2 mutations by PCR-SSCPSequencing analysis. Mutations in CHEK2 were found in 14 separate patients who had no family relationship (14/145 i.e. $9.65 \%)$. None of the patients carried more than one CHEK2 mutation. All mutations were visualized as extra bands with altered electrophoretic mobility in the mutant samples 
I

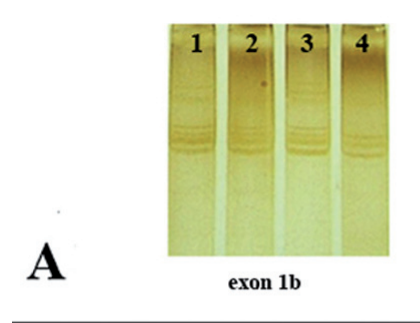

II

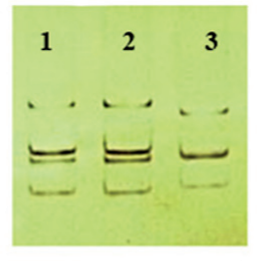

exon 12
III

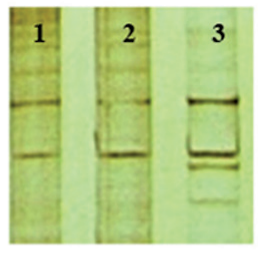

exon 13
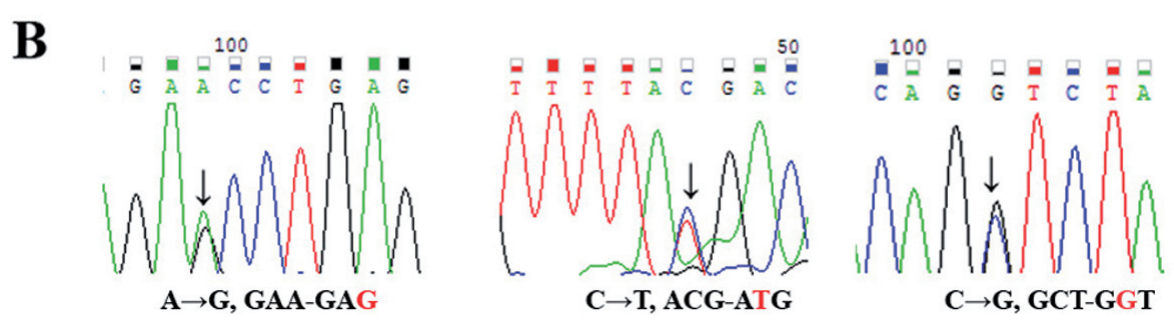

Figure $1 \mathrm{~A}$ - SSCP analysis of CHEK2 gene of I - exon 1b, aberrant profile (lanes 1, 2, 3) and normal profile (lane 4); II - exon 12, aberrant profile (lanes 1,2 ) and normal profile (lane 3); III-exon 13 aberrant profile (lane 3 ) and normal profile (lanes 1, 2). The normal profile comes from healthy controls; B - Sequence analysis with the forward primer of the samples with the respective mutant pattern

(Fig. 1, I A - lanes 1, 2, 3; II A - lane 1 and 2; III A - lane 3). Healthy persons were used as negative controls in the PCRSSCP analysis (Fig. 1, I A - lane 4; II A - lane 3; III A - lanes 1 and 2 ). The PCR products with aberrant migration on the SSCP gel were purified and sequenced to determine the type of mutation (Table 2). CHEK2 mutations were mapped to exons $1 \mathrm{~b}, 12$ and 13. All of the found alterations were novel and were either missense or silent. We found nine identical silent variants A to $G$ at a position 237 bp (Glu79Glu) (Fig. 1, I B), three $\mathrm{C}$ to $\mathrm{T}$ base substitutions at a position $1427 \mathrm{bp}$, leading to Thr476Met amino acid change (Fig. 1, II B), and two $\mathrm{C}$ to $\mathrm{G}$ substitutions at a position 1520 bp altering the amino acid composition of the protein (Ala507Gly) (Fig. 1, III B).

Methylation analysis of the $C H E K 2$ promoter. Methylation-sensitive SSCP was used to determine the methylation status of two distinct CpG clusters located upstream of the ATG. To assess the methylation status two controls - negative (blood DNA isolated from healthy persons) and positive (totally methylated in vitro DNA) were used in each electrophoresis. In all tumor samples the distal CpG cluster is not methylated and showed migration profile identical with the negative control. Reversely, the proximal CpG cluster is totally methylated and had migration profile identical with the positive control in all of the cases.

Mutational gene status in relation to clinico-pathological and molecular characteristics. To estimate the clinical impact of altered CHEK2 by itself, independent of the type of alteration, we compared the CHEK2 genetic status of the patients with standard prognostic factors including age of diagnosis, tumor size $(\mathrm{T})$, nodal $(\mathrm{N})$ status, grade of malignancy $(\mathrm{G})$, histological type (HT), estrogen (ER) and progesterone receptor (PR) status (Table 3; Column "CHEK2 status"). In addition to the clinico-pathological characteristics of the patients, several tumor molecular characteristics previously found as $p 53, A T M, P I K 3 C A, H E R 2$ status were included in the analysis [40] (Table 3). We found that CHEK2 mutational status correlated significantly with lobular histological type $(\mathrm{p}=0.04)$. A tendency for higher frequency of the $\mathrm{PR}^{+}$status in $C H E K 2^{+}$patients was found $(\mathrm{p}=0.092)$.

To identify if the specific type of the found CHEK2 variants has a specific clinical impact we further divided the CHEK2 positive patients into two groups: one with missense variants and the other - with silent variants. Patients with the missense

Table 2. Spectrum of CHEK2 mutations found in the studied Bulgarian $\mathrm{BC}$ patients.

\begin{tabular}{|c|c|c|c|c|c|c|}
\hline Number of patients & Exon & Position (bp) & Codon & Nucleotide change & Amino acid change & Type of mutation \\
\hline 9 & $1 b$ & 237 & 79 & $A \rightarrow G ; G A A-G A G$ & Glu - Glu & $\begin{array}{l}\text { Silent } \\
\text { Glu79Glu }(A>G)\end{array}$ \\
\hline 3 & 12 & 1427 & 476 & $\mathrm{C} \rightarrow \mathrm{T} ; \mathrm{ACG}-\mathrm{ATG}$ & Thr - Met & $\begin{array}{l}\text { Missense } \\
\text { Thr476Met }(\mathrm{C}>\mathrm{T})\end{array}$ \\
\hline 2 & 13 & 1520 & 507 & $\mathrm{C} \rightarrow \mathrm{G} ; \mathrm{GCT}-\mathrm{GGT}$ & Ala507Gly & $\begin{array}{l}\text { Missense } \\
\text { Ala-Gly }(\mathrm{C}>\mathrm{G})\end{array}$ \\
\hline
\end{tabular}


Table 3. CHEK2 status in relation to clinico-pathological and molecular characteristics

\begin{tabular}{|c|c|c|c|c|c|c|c|c|c|c|c|}
\hline \multicolumn{2}{|c|}{ Variable } & \multicolumn{4}{|c|}{ CHEK2 status } & \multicolumn{3}{|c|}{ CHEK2 missense variants } & \multicolumn{3}{|c|}{ CHEK2 silent variants } \\
\hline & & $\begin{array}{c}\text { Total } \\
(\mathrm{n}=145)\end{array}$ & $\begin{array}{l}\text { Positive } \\
(\mathrm{n}=14)\end{array}$ & $\begin{array}{l}\text { Negative } \\
(\mathrm{n}=131)\end{array}$ & pvalue & $\begin{array}{c}\text { Positive } \\
(\mathrm{n}=5)\end{array}$ & $\begin{array}{l}\text { Negative } \\
(\mathrm{n}=140)\end{array}$ & p value & $\begin{array}{c}\text { Positive } \\
(\mathrm{n}=9)\end{array}$ & $\begin{array}{l}\text { Negative } \\
(\mathrm{n}=136)\end{array}$ & p value \\
\hline \multirow[t]{4}{*}{ Age } & Years (mean) & 54.4 & 54.71 & 54.37 & 1 & 53.8 & 54.42 & 0.655 & 55.2 & & 0.722 \\
\hline & Range & $29-88$ & $32-74$ & $29-88$ & & $32-74$ & $29-88$ & & $35-70$ & $29-88$ & \\
\hline & $<50$ & 52 & 5 & 47 & & 1 & 51 & & 4 & 48 & \\
\hline & $>=50$ & 93 & 9 & 84 & & 4 & 89 & & 5 & 88 & \\
\hline \multirow[t]{2}{*}{ Tumor size } & $\mathrm{T} 1$ & 65 & 8 & 57 & 0.401 & 3 & 62 & 0.657 & 5 & 60 & 0.514 \\
\hline & $\mathrm{T} 2-\mathrm{T} 4$ & 80 & 6 & 74 & & 2 & 78 & & 4 & 76 & \\
\hline \multirow[t]{2}{*}{$\mathrm{N}$ status } & N0 & 92 & 8 & 84 & 0.771 & 3 & 89 & 1 & 5 & 87 & 0.724 \\
\hline & $\mathrm{N}+$ & 53 & 6 & 47 & & 2 & 51 & & 4 & 49 & \\
\hline \multirow[t]{3}{*}{ G } & G1 & 6 & 1 & 5 & 0.473 & 1 & 5 & 0.193 & & 6 & 0.332 \\
\hline & G2 & 103 & 8 & 95 & & 3 & 100 & & 5 & 98 & \\
\hline & G3 & 36 & 5 & 31 & & 1 & 35 & & 4 & 32 & \\
\hline \multirow[t]{2}{*}{ Histological type } & Lobular & 15 & 4 & 11 & 0.04 & 2 & 13 & 0.083 & 2 & 13 & 0.234 \\
\hline & Ductal & 130 & 10 & 120 & & 3 & 127 & & 7 & 123 & \\
\hline \multirow[t]{2}{*}{ ER expression } & Positive & 81 & 8 & 73 & 1 & 5 & 76 & 0.067 & 3 & 78 & 0.183 \\
\hline & Negative & 64 & 6 & 58 & & - & 64 & & 6 & 58 & \\
\hline \multirow[t]{2}{*}{ PR expression } & Positive & 81 & 11 & 70 & 0.092 & 2 & 79 & 0.654 & 9 & 72 & 0.004 \\
\hline & Negative & 64 & 3 & 61 & & 3 & 61 & & & 64 & \\
\hline \multirow[t]{2}{*}{ p53 mutation } & Positive & 16 & 1 & 15 & 1 & 1 & 15 & 1 & & 16 & 0.597 \\
\hline & Negative & 129 & 13 & 116 & & 4 & 125 & & 9 & 120 & \\
\hline \multirow[t]{2}{*}{ ATM mutation } & Positive & 11 & 2 & 9 & 0.287 & 2 & 9 & 0.046 & & 11 & 1 \\
\hline & Negative & 134 & 12 & 122 & & 3 & 131 & & 9 & 125 & \\
\hline \multirow[t]{2}{*}{ PIK3CA mutation } & Positive & 45 & 5 & 40 & 0.764 & 2 & 43 & 1 & 3 & 42 & 1 \\
\hline & Negative & 99 & 9 & 90 & & 3 & 96 & & 6 & 93 & \\
\hline \multirow[t]{3}{*}{ HER2 } & Overexpressed & 21 & 1 & 20 & 0.679 & 1 & 20 & 1 & 1 & 20 & 1 \\
\hline & Normal & 78 & 8 & 70 & & 3 & 75 & & 4 & 74 & \\
\hline & Unknown & 46 & Unknown & Unknown & & Unknown & Unknown & & Unknown & Unknown & \\
\hline
\end{tabular}

types Thr476Met (three patients) and Ala507Gly (two patients) were combined in a common group due to their limited number. The results showed that CHEK2 missense variants were significantly associated with $A T M^{+}$status $(\mathrm{p}=0.046)(\mathrm{Ta}-$ ble 3; Column "Missense variants"). All patients with CHEK2 missense mutations were ER positive $(\mathrm{p}=0.067)$. Statistically significant correlation ( $\mathrm{p}=0.004)$ was found between the silent variants and PR status (Table 3; Column "Silent variants"). All patients with silent variants were progesterone receptor positive.

Mutational gene status and overall survival. Overall survival of the studied group was estimated to $75.86 \%(110 / 145)$. Kaplan-Meier analysis showed a decrease in OS of patients with $C H E K 2^{+}$status compared to CHEK2 though not statistically significant $(\mathrm{p}=0.6301)$.

To estimate the hazard ratio (HR) according to the CHEK2 status, univariate and multivariate Cox proportional-hazards regression model was used (Table 4). The multivariate model included the clinico-pathological and molecular characteristics of the patients discussed above. A threefold independent increase in the risk of death $(\mathrm{HR}=3.295,95 \% \mathrm{CI} 0.850-12.778$, $\mathrm{p}=0.085)$ in $C H E K 2^{+}$patients was found.
Another independent marker which strongly correlated with increased mortality rate was the tumor size $(\mathrm{HR}=4.701$, $95 \%$ CI 1.536-1.392, $\mathrm{p}=0.007)$. Negative, though not independent effect on survival had p53 mutations ( $\mathrm{HR}=2.28,95 \%$ CI $0.999-5.239, \mathrm{p}=0.05$ ).

\section{Discussion}

Breast cancer is rather too heterogeneous and no general molecular phenotype related of the disease could be outlined. Breast carcinogenesis is a result of disruption of cellular pathways, in which key tumor suppressor genes and protooncogenes are involved: $B R C A 1$ and $B R C A 2$ genes, $p 53, A T M$, PIK3CA, HER2, CHEK2, PTEN and others. Of the BC related genes, CHEK2 is a key kinase implicated in the regulation of the cell cycle. Despite the intensive studies during the recent years, the complete mutational spectrum and the clinical significance of CHEK 2 have not yet been fully elucidated. The established CHEK2 mutational profile shows considerable heterogeneity, both with respect to spectrum and frequency of mutations, and their presence (or absence) in the different populations $[6,42]$. Several moderately penetrant CHEK2 
Table 4. Multivariate and Univariate survival analysis

\begin{tabular}{|c|c|c|c|c|c|c|}
\hline \multirow{2}{*}{ Factor } & \multicolumn{3}{|c|}{ Multivariate } & \multicolumn{3}{|c|}{ Univariate } \\
\hline & HR & $95 \% \mathrm{CI}$ & $p$ & HR & $95 \% \mathrm{CI}$ & $p$ \\
\hline CHEK2 & 3.295 & $0.85-12.778$ & 0.085 & 1.290 & $0.455-3.654$ & 0.632 \\
\hline p53 & 1.310 & $0.456-3.757$ & 0.616 & 2.288 & $0.999-5.239$ & 0.050 \\
\hline PIK3CA & 0.480 & $0.179-1.287$ & 0.145 & 0.502 & $0.219-1.149$ & 0.103 \\
\hline ATM & 1.958 & $0.391-9.802$ & 0.414 & 1.084 & $0.331-3.543$ & 0.894 \\
\hline HER2 & 0.874 & $0.300-2.547$ & 0.805 & 1.266 & $0.505-3.174$ & 0.616 \\
\hline Age & 0.716 & $0.286-1.793$ & 0.476 & 1.283 & $0.629-2.620$ & 0.493 \\
\hline Grade of malignancy & 1.332 & $0.539-3.293$ & 0.535 & 1.469 & $0.764-2.824$ & 0.249 \\
\hline Tumor size & 4.701 & $1.536-1.392$ & 0.007 & 1.957 & $0.958-3.996$ & 0.065 \\
\hline Nodal status & 0.962 & $0.381-2.425$ & 0.934 & 0.984 & $0.495-1.956$ & 0.963 \\
\hline Estrogen receptor & 0.953 & $0.375-2.424$ & 0.920 & 1.440 & $0.725-2.859$ & 0.297 \\
\hline Progesterone receptor & 0.427 & 0.174-1.048 & 0.063 & 0.525 & $0.268-1.027$ & 0.060 \\
\hline
\end{tabular}

Abbreviations: HR, hazard ratio; CI, confidence interval; Significant $p$ values are in bold

cancer susceptibility mutations, increasing the risk of breast cancer have been detected: 1100delC, I157T, S428F and del5395 $[18,28,43-45]$. These variants seem not to be present in all populations; their frequency varies in the general population, and is higher in breast cancer patients. In addition, some rare, missense mutations, small deletions and nonsense mutations have been identified [21, 46-48]. Some of these missense CHEK2 mutants have been shown to be unstable or to affect the activation of the encoded protein, indicating that they are likely to be pathogenic [49-50]. No data on CHEK2 mutational spectrum in Bulgarian patients with breast cancer was so far available. Our results showed specificity in the spectrum of CHEK2 mutations. Interestingly, the CHEK2 variants discussed above are not present in the studied group of Bulgarian patients. However, novel alterations were found: Glu79Glu (A to $\mathrm{G}$ ), Thr476Met (C to T), Ala507Gly (C to $\mathrm{G}$ ). The mutation Thr476Met ( $\mathrm{C}$ to $\mathrm{T}$ ) maps to the kinase domain of CHEK2 and is likely to disrupt the main function of the protein. The Glu79Glu (A to G) variant is located between SCD and FNA domains, and the mutation Ala507Gly ( $C$ to $G$ ) is close to the $\mathrm{C}$ - terminal. Although these two variants do not affect the functional domains of the protein, they may alter the stability of mRNA and protein as well as its interactions with other proteins.

Our results showed that mutational CHEK2 status significantly correlated with several clinico-pathological parameters including lobular histological type and positive progesterone receptor status. Statistically significant correlation with the lobular histological type is visible when mutated CHEK2 is considered independent of the type of mutation. The observation was not registered when separate variants were taken into account, probably due to the smaller size of the excerpt. However, the tendency that patients with a CHEK2 alteration had lobular type of breast carcinoma remained. Invasive lobular carcinoma is the second most common type of breast cancer (10-20\%). It is considered to have a better prognosis than ductal carcinoma [51] with better survival rates of patients
[52]. Similar to our findings Huzarski et al. [53] suggested a strong association of CHEK2 I157T allele with lobular breast carcinoma among BC patients in Poland. Progesterone and estrogen receptors are considered as breast cancer biomarkers with implications in prognosis and therapy. Over $70 \%$ of breast cancers are ER and PR positive [54], and often respond to selective ER modulators such as Tamoxifen, which acts to inhibit estrogen by blocking the ER [55]. When hormone therapy is applied in ER positive patients, good therapeutic outcome is to be expected. Several studies found a correlation between 1100 delC mutation and hormone receptor positive status [56, 57].

In addition to clinico-pathological parameters, the genetic status of several BC related genes was investigated in relation to CHEK2 status. Most of these genes are involved in pathways which regulate the cellular response to genotoxic stress [58]. CHEK2 kinase directly interacts with some of these proteins, including ATM kinase and p53 transcription factor. In this study we found an interesting association between CHEK2 missense mutation and ATM positive status. ATM gene is a sensor of DNA damage and upon ATM inactivation the signal transduction to the target genes is disrupted. The impossibility of effective DNA repair leads to accumulation of mutations, thus the dysfunction of ATM and CHEK2 can further facilitate tumorigenesis $[59,60]$. We also found a relationship between $C H E K 2$ and $p 53$ mutational gene status. Of a total of sixteen $p 53$ positive tumors [40] only one had in addition a mutation in CHEK2. It seems like $p 53$ and CHEK2 mutations somehow are mutually incompatible. In support to this is the observation that germ-line CHEK2 mutations are present in Li-Fraumeni families with a wild-type $p 53$.

Although mutated CHEK2 correlated with more favorable clinical characteristics (lobular histological type and PR+ status), it increased the risk of death in positive patients. A possible explanation of this observation is that CHEK2 mutational status has by itself a negative prognostic charge, which is reduced under the influence of the positive prognostic indica- 
tors. The positive PR status by itself, as well as the lobular type of tumors, presumes a good therapeutic response and better outcome of patients. In combination with CHEK2 mutations, however, a slight increase in the risk of death (Univariate Cox proportional hazard regression model) and decrease in overall survival (Kaplan-Meier analysis) were registered. When the influence of all studied tumors and molecular characteristics are taken into account and their effect is neglected (in the Multivariate Cox proportional hazard regression model), the independent impact of mutated CHEK2 can be observed. Thus, the independent $\mathrm{CHEK2}^{+}$considerably increased the risk of death in mutation carriers.

Several studies presume the implication of epigenetic (in addition to genetic) mechanisms in loss of CHEK2 function [20]. A possible epigenetic cancer related event is the promoter hypermethylation. Hypermethylation in CHEK2 promoter was found in lung [34], colorectal cancer [38] and Hodgkin's lymphoma cell lines [36]. Higher CHEK2 hypermethylation frequency was detected in non-small-cell lung carcinoma - 28.1\%, and in colorectal cancer - 10\% [34, 38]. In gliomas CHEK2 promoter was hypermethylated only in its proximal high $\mathrm{CpG}$ dinucleotides region [39]. With respect to BC, limited data available showed lack of abnormal CHEK2 hypermethylation $[20,29,61]$. This was also supported by our results, which are similar to the results of Williams LH et al. [20]. The data indicated that the proximal CpG cluster is totally methylated in all tumor samples. Such methylation profile is also present in the studied normal tissue samples, which indicates that it is probably not related to breast tumorigenesis. Reversely, the distal CpG cluster is not methylated either in tumor samples, or in the controls. This data suggest that the distal $\mathrm{CpG}$ region may not be significant in regulation of gene transcription and therefore in tumorigenesis.

\section{Conclusion}

This study provided the first data on the genetic profile and promoter methylation status of CHEK2 gene in Bulgarian breast cancer patients. Our data indicate the significance of genetic inactivation of CHEK2 in sporadic breast carcinogenesis. However, CHEK2 hypermethylation is probably less essential in this cancer type. Several novel CHEK2 variants were registered presuming specificity of CHEK2 mutational profile for the Bulgarian population. Though CHEK2 mutational status correlated with more favorable clinical characteristics, including positive progesterone receptor and lobular histological type, it independently increased the risk of death in these patients.

Acknowledgements: Authors express their gratitude to Dr. Ivan Gavrilov and Dr. Maria Nacheva, the National Oncological Centre Hospital - Sofia, who provided the tumor samples and clinical data of patients and to Georgi Antov, Institute of Plant physiology and Genetics for the technical assistance. This work was supported by the Bulgarian Ministry of Education and Science; project DO 02-310/08.

\section{References}

[1] VALERIANOVA Z, VUKOV M, DIMITROVA N, editors. Cancer incidence in Bulgaria 2009. Sofia: AVIS-24 Ltd., 2011.

[2] BECKMANN MW, NIEDERACHER D, SCHNURCH HG, GUSTERSON BA, BENDER HG. Multistep carcinogenesis of breast cancer and tumour heterogeneity. J Mol Med 1997; 75: 429-439.

[3] SIMPSON PT, REIS-FILHO JS, GALE T, LAKHANI SR. Molecular evolution of breast cancer. J Pathol 2005; 205: 248-254.

[4] ZHOU BB, ELLEDGE SJ. The DNA damage response: putting checkpoints in perspective. Nature 2000; 408: 433-439. http: //dx.doi.org/10.1038/35044005

[5] BARTEK J, LUKAS J. Chk1 and Chk2 kinases in checkpoint control and cancer. Cancer Cell 2003; 3: 421-429. http: // dx.doi.org/10.1016/S1535-6108(03)00110-7

[6] NEVANLINNA H, BARTEK J. The CHEK2 gene and inherited breast cancer susceptibility. Oncogene 2006; 25: 5912-5919. http: //dx.doi.org/10.1038/sj.onc.1209877

[7] LUKAS C, BARTKOVA J, LATELLA L, FALCK J, MAILAND $\mathrm{N}$ et al. DNA damage-activated kinase Chk2 is independent of proliferation or differentiation yet correlates with tissue biology. Cancer Res 2001; 61: 4990-4993.

[8] AHN JY, SCHWARZ JK, PIWNICA-WORMS H, CANMAN CE. Threonine 68 phosphorylation by ataxia telangiectasia mutated is required for efficient activation of Chk2 in response to ionizing radiation. Cancer Res 2000; 60: 5934-5936.

[9] MATSUOKA S, HUANG M, ELLEDGE SJ. Linkage of ATM to cell cycle regulation by the Chk2 protein kinase. Science 1998; 282: 1893-1897. http: //dx.doi.org/10.1126/ science.282.5395.1893

[10] MATSUOKA S, ROTMAN G, OGAWA A, SHILOH Y, TAMAI K et al. Ataxia telangiectasia-mutated phosphorylates Chk2 in vivo and in vitro. Proc Natl Acad Sci USA 2000; 97: 10389-10394. http: //dx.doi.org/10.1073/ pnas. 190030497

[11] TOMINAGA K, MORISAKI H, KANEKO Y, FUJIMOTO A, TANAKA $\mathrm{T}$ et al. Role of human Cds1 (Chk2) kinase in DNA damage checkpoint and its regulation by p53. J Biol Chem 1999; 274: 31463-31467. http: //dx.doi.org/10.1074/ jbc. 274.44 .31463

[12] FALCK J, MAILAND N, SYLJUASEN RG, BARTEK J, LUKAS J. The ATM-Chk2-Cdc25A checkpoint pathway guards against radioresistant DNA synthesis. Nature 2001; 410: 842-847. http: //dx.doi.org/10.1038/35071124

[13] LEE JS, COLLINS KM, BROWN AL, LEE CH, CHUNG JH. hCds1-mediated phosphorylation of BRCA1 regulates the DNA damage response. Nature 2000; 404: 201-204. http: //dx.doi.org/10.1038/35004614

[14] CHEHAB NH, MALIKZAY A, APPEL M, HALAZONETIS TD. Chk2/hCds1 functions as a DNA damage checkpoint in G(1) by stabilizing p53. Genes Dev 2000; 14: 278-288.

[15] SHIEH SY, AHN J, TAMAI K, TAYA Y, PRIVES C. The human homologs of checkpoint kinases Chk1 and Cds1 (Chk2) phosphorylate p53 at multiple DNA damage-inducible sites. Genes Dev 2000; 14: 289-300. 
[16] BARTEK J, FALCK J, LUKAS J. CHK2 kinase: a busy messenger. Nat Rev Mol Cell Biol 2001; 2: 877-886. http: //dx.doi. org/10.1038/35103059

[17] BELL DW, VARLEY JM, SZYDLO TE, KANG DH, WAHRER DC et al. Heterozygous germ line hCHK2 mutations in LiFraumeni syndrome. Science 1999; 286: 2528-2531. http: //dx.doi.org/10.1126/science.286.5449.2528

[18] MEIJERS-HEIJBOER H, VAN DEN OUWELAND A, KLIJN J, WASIELEWSKI M, DE SNOO A et al. Low-penetrance susceptibility to breast cancer due to CHEK2 $\left(^{*}\right) 1100$ delC in noncarriers of BRCA1 or BRCA2 mutations. Nat Genet 2002; 31: 55-59. http: //dx.doi.org/10.1038/ng879

[19] VAHTERISTO P, BARTKOVA J, EEROLA H, SYRJA “ KOSKI $\mathrm{K}$, OJALA $S$ et al. A CHEK2 genetic variant contributing to a substantial fraction of familial breast cancer. Am J Hum Genet 2002; 71: 432-438. http: //dx.doi.org/10.1086/341943

[20] WILLIAMS LH, CHOONG D, JOHNSON SA, CAMPBELL IG. Genetic and epigenetic analysis of CHEK2 in sporadic breast, colon, and ovarian cancers. Clin Cancer Res 2006; 12: 6967-6972. http: //dx.doi.org/10.1158/1078-0432.CCR-06-1770

[21] INGVARSSON S, SIGBJORNSDOTTIR BI, HUIPING C, HAFSTEINSDOTTIR SH, RAGNARSSON G et al. Mutation analysis of the CHK2 gene in breast carcinoma and other cancers. Breast Cancer Res 2002; 4(3): R4. http: //dx.doi. org/10.1186/bcr435

[22] REDDY A, YUILLE M, SULLIVAN A, REPELLIN C, BELL A et al. Analysis of CHK2 in vulval neoplasia. Br J Cancer 2002; 86: 756-760. http: //dx.doi.org/10.1038/sj.bjc.6600131

[23] DONG X, WANG L, TANIGUCHI K, WANG X, CUNNINGHAM JM et al. Mutations in CHEK2 associated with prostate cancer risk. Am J Hum Genet 2003; 72: 270-280. http: //dx.doi. org/10.1086/346094

[24] TAVOR S, TAKEUCHI S, TSUKASAKI K, MILLER CW, HOFMANN WK et al. Analysis of the CHK2 gene in lymphoid malignancies. Leuk Lymphoma 2001; 42: 517-520. http: //dx.doi.org/10.3109/10428190109064610

[25] HOFMANN WK, MILLER CW, TSUKASAKI K, TAVOR $\mathrm{S}$, IKEZOE $\mathrm{T}$ et al. Mutation analysis of the DNA-damage checkpoint gene CHK2 in myelodysplastic syndromes and acute myeloid leukemias. Leuk Res 2001; 25: 333-338. http: //dx.doi.org/10.1016/S0145-2126(00)00130-2

[26] HARUKI N, SAITO H, TATEMATSU Y, KONISHI H, HARANO T et al. Histological type-selective, tumor-predominant expression of novel CHK1 isoform and infrequent in vivo somatic CHK2 mutation in small cell lung cancer. Cancer Res 2000; 60(17): 4689-4692.

[27] CYBULSKI C, GORSKI B, HUZARSKI T, MASOJC B, MIERZEJEWSKI $M$ et al. CHEK2 is a multiorgan cancer susceptibility gene. Am J Hum Genet 2001; 75: 1131-1135. http: //dx.doi.org/10.1086/426403

[28] WEISCHER M, BOJESEN SE, TYBJAERG-HANSEN A, AXELSSON CK, NORDESTGAARD BG. Increased risk of breast cancer associated with $\mathrm{CHEK} 2{ }^{\star} 1100 \mathrm{delC}$. J Clin Oncol 2007; 25: 57-63. http: //dx.doi.org/10.1200/ LCO.2005.05.5160

[29] SULLIVAN A, YUILLE M, REPELLIN C, REDDY A, REELFS $\mathrm{O}$ et al. Concomitant inactivation of p53 and Chk2 in breast cancer. Oncogene 2002; 121: 1316-1324. http: //dx.doi. org/10.1038/sj.onc. 1205207

[30] SAKAI T, TOGUCHIDA J, ONTANI N, YANDELL DW, RAPAPORT JM et al. Allele-specific hypermethylation of the retinoblastoma tumor-suppressor gene. Am J Hum Genet 1991; 48: 880-888.

[31] HERMAN JG, LATIF F, WENG Y, LERMAN MI, ZBAR B et al. Silencing of the VHL tumor-suppressor gene by DNA methylation in renal carcinoma. Proc Natl Acad Sci USA 1994; 91: 9700-9704. http: //dx.doi.org/10.1073/pnas.91.21.9700

[32] AI L, VO QN, ZUO C, LI L, LING W et al. Ataxia-telangiectasia-mutated (ATM) gene in head and neck squamous cell carcinoma: promoter hypermethylation with clinical correlation in 100 cases. Cancer Epidemiol Biomarkers Prev 2004; 13: 150-156. http: //dx.doi.org/10.1158/1055-9965. EPI-082-3

[33] DOBROVIC A, SIMPFENDORFER D. Methylation of the BRCA1 Gene in Sporadic Breast Cancer. Cancer Res 1997; 57: 3347-3350.

[34] KIM DS, KIM MJ, LEE JY, LEE SM, CHOI JE et al. Epigenetic inactivation of checkpoint kinase 2 gene in non-small cell lung cancer and its relationship with clinicopathological features. Lung Cancer 2009; 65: 247-250. http: //dx.doi.org/10.1016/ j.lungcan.2009.03.011

[35] ZHANG P, WANG J, GAO W, YUAN BZ, ROGERS J et al. CHK2 kinase expression is downregulated due to promotermethylation in non-small cell lung cancer. Mol Cancer 2004; 3: 14-23. http: //dx.doi.org/10.1186/1476-4598-3-14

[36] KATO N, FUJIMOTO H, YODA A, OISHI I, MATSUMURA $\mathrm{N}$ et al. Regulation of Chk2 gene expression in lymphoid malignancies: involvement of epigenetic mechanisms in Hodgkin's lymphoma cell lines. Cell Death Differ 2004; 11: 153-161. http: //dx.doi.org/10.1038/sj.cdd.4401461

[37] TORT F, HERNANDEZ S, BEA S, MARTINEZ A, ESTELLER $\mathrm{M}$ et al. CHK2-decreased protein expression and infrequent genetic alterations mainly occur in aggressive types of nonHodgkin lymphomas. Blood 2002; 100: 4602-4608. http: //dx.doi.org/10.1182/blood-2002-04-1078

[38] REZAPOUR S, MEUTH M. EMAST Instability and CHEK2 Promoter Analysis in Colorectal Cancer. Iranian J Publ Health 2005; 34: 54-55.

[39] WANG H, WANG S, SHEN L, CHEN Y, ZHANG X et al. Chk2 down-regulation by promoter hypermethylation in human bulk gliomas. Life Sci 2009; 86: 185-191. http: //dx.doi. org/10.1016/j.lfs.2009.11.023

[40] BOZHANOV SS, ANGELOVA SG, KRASTEVA ME, MARKOV TL, CHRISTOVA SL et al. Alterations in p53, BRCA1, ATM, PIK3CA, and HER2 genes and their effect in modifying clinicopathological characteristics and overall survival of Bulgarian patients with breast cancer. J Cancer Res Clin Oncol 2010; 136: 1657-1669. http://dx.doi.org/10.1007/s00432-010$\underline{0824-9}$

[41] LIU WD, ZHONG BY, ZHANG YD, CHOI GS. Mutation analysis of the checkpoint kinase 2 gene in colorectal cancer cell lines. Chin Med J (Engl) 2007; 120: 2119-2123.

[42] ANTONI L, SODHA N, COLLINS I, GARRETT MD. CHK2 kinase: cancer susceptibility and cancer therapy - two sides 
of the same coin? Nat Rev Cancer 2007; 7: 925-936. http: //dx.doi.org/10.1038/nrc2251

[43] KILPIVAARA O, VAHTERISTO P, FALCK J, SYRJAKOSKI $\mathrm{K}$, EEROLA H et al. CHEK2 variant I157T may be associated with increased breast cancer risk. Int J Cancer 2004; 111: 543-547. http: //dx.doi.org/10.1002/ijc.20299

[44] SHAAG A, WALSH T, RENBAUM P, KIRCHHOFF T, NAFA $\mathrm{K}$ et al. Functional and genomic approaches reveal an ancient CHEK2 allele associated with breast cancer in the Ashkenazi Jewish population. Hum Mol Genet 2005; 14: 555-563. http: //dx.doi.org/10.1093/hmg/ddi052

[45] CYBULSKI C, WOKOŁORCZYK D, HUZARSKI T, BYRSKI T, GRONWALD J et al. A deletion in CHEK2 of 5,395 bp predisposes to breast cancer in Poland. Breast Cancer Res Treat 2007; 102: 119-122. http: //dx.doi.org/10.1007/s10549006-9320-y

[46] SODHA N, BULLOCK S, TAYLOR R, MITCHELL G, GUERTL-LACKNER B et al. CHEK2 variants in susceptibility to breast cancer and evidence of retention of the wild type allele in tumours. Br J Cancer 2002a; 87: 1445-1448. http: //dx.doi.org/10.1038/sj.bjc.6600637

[47] SCHUTTE M, SEAL S, BARFOOT R, MEIJERS-HEIJBOER $\mathrm{H}$, WASIELEWSKI M et al. Breast Cancer Linkage Consortium: Variants in CHEK2 other than 1100delC do not make a major contribution to breast cancer susceptibility. Am J Hum Genet 2003; 72: 1023-1028. http: //dx.doi.org/10.1086/ $\underline{373965}$

[48] DUFAULT MR, BETZ B, WAPPENSCHMIDT B, HOFMANN W, BANDICK $\mathrm{K}$ et al. Limited relevance of the CHEK2 gene in hereditary breast cancer. Int J Cancer 2004; 110: 320-325. http: //dx.doi.org/10.1002/ijc.20073

[49] WU X, WEBSTER SR, CHEN J. Characterization of tumor-associated Chk2 mutations Characterization of tumor-associated Chk2 mutations. J Biol Chem 2001; 276: 2971-2974. http: //dx.doi.org/10.1074/jbc.M009727200

[50] SODHA N, MANTONI TS, TAVTIGIAN SV, EELES R, GARRETT MD. Rare germ line CHEK2 variants identified in breast cancer families encode proteins that show impaired activation. Cancer Res 2006; 66: 8966-8970. http: //dx.doi. org/10.1158/0008-5472.CAN-06-1990

[51] YODER BJ, WILKINSON EJ, MASSOLL NA. Molecular and morphologic distinctions between infiltrating ductal and lobular carcinoma of the breast. Breast J 2007; 13: 172-179. http: //dx.doi.org/10.1111/j.1524-4741.2007.00393.x
[52] HSIAO YH, TSAI HD, CHOU MC, MAN YG. The myoepithelial cell layer may serve as a potential trigger factor for different outcomes of stage-matched invasive lobular and ductal breast cancers. Int J Biol Sci 2011; 7: 147-153.

[53] HUZARSKI T, CYBULSKI C, DOMAGALA W, GRONWALD J, BYRSKI T et al. Pathology of breast cancer in women with constitutional CHEK2 mutations. Breast Cancer Res Treat 2005; 90: 187-189. http: //dx.doi.org/10.1007/s10549-004$\underline{3778-2}$

[54] KESHTGAR M, DAVIDSON T, PIGOTT K, FALZON M, JONES A. Current status and advances in management of early breast cancer. Int J Surg 2010; 8: 199-202. http: //dx.doi. org/10.1016/j.ijsu.2010.02.004

[55] JORDAN VC. Tamoxifen (ICI46, 474) as a targeted therapy to treat and prevent breast cancer. Br J Pharmacol 2006; 147: S269-276.

[56] DE BOCK GH, SCHUTTE M, KROL-WARMERDAM EM, SEYNAEVE C, BLOM J et al. Tumour characteristics and prognosis of breast cancer patients carrying the germline CHEK2^1100delC variant. J Med Genet 2004; 41: 731-735. http: //dx.doi.org/10.1136/jmg.2004.019737

[57] KILPIVAARA O, BARTKOVA J, EEROLA H, SYRJAKOSKI $\mathrm{K}$, VAHTERISTO $\mathrm{P}$ et al. Correlation of CHEK2 protein expression and c.1100delC mutation status with tumor characteristics among unselected breast cancer patients. Int J Cancer 2005; 113: 575-580. http: //dx.doi.org/10.1002/ijc.20638

[58] MCKINNON PJ, CALDECOTT KW. DNA strand break repair and human genetic disease. Annu Rev of Genomics and Hum Genet 2007; 8: 37-55. http: //dx.doi.org/10.1146/annurev.genom.7.080505.115648

[59] HIRAO A, KONG YY, MATSUOKA S, WAKEHAM A, RULAND J et al. DNA damage-induced activation of p53 by the checkpoint kinase Chk2. Science 2000; 287: 1824-1827. http: //dx.doi.org/10.1126/science.287.5459.1824

[60] TAKAI H, NAKA K, OKADA Y, WATANABE M, HARADA $\mathrm{N}$ et al. Chk2-deficient mice exhibit radioresistance and defective p53-mediated transcription. EMBO J 2002; 21: 5195-5205. http: //dx.doi.org/10.1093/emboj/cdf506

[61] PAL R, SRIVASTAVA N, CHOPRA R, GOCHHAIT S, GUPTA P et al. Investigation of DNA damage response and apoptotic gene methylation pattern in sporadic breast tumors using high throughput quantitative DNA methylation analysis technology. Mol Cancer 2010; 9: 303. http: //dx.doi. org/10.1186/1476-4598-9-303 